\title{
EVOKING THE ETHICS OF FREEDOM IN THE INTERESTING NARRATIVE OF THE LIFE OF OLAUDAH EQUIANO
}

\author{
Arvind Dahal
}

\begin{abstract}
In this article an attempt has been made to analyze how the abolitionist literature of the Enlightenment Period worked to evoke sympathy for the slaves and hatred for the slavers by using the same doctrines used by the Christians to inflict atrocities and exert superiority over NonChristians. In doing so, the article explores how these narratives debunked the notion of enlightenment and argues that it was used not to emancipate mankind but to endorse slavery.
\end{abstract}

Key Words: Sympathy, Romantic Sympathy, transatlantic slave trade, Christianity, Abolitionism

Olaudah Equiano's magnum opus The Interesting Narrative of the Life of Olaudah Equiano(1789) overplays Equiano's transformation from 'slave to subject' and 'sinner to saved' through spiritual self-possession which evokes the ethics of freedom. This paper seeks to argue that it is the debunking of Briton's pride of their superiority into sympathy for the wants and miseries of their sable brethren, and reposing strong faith in divine providence. It has sought to contextualize transatlantic slave trade, during the course of the eighteenth century invoking the sensational rhetorical elements of romantic sympathy vis-à-vis the ongoing debate over abolition implicitly critiquing the mysterious ways of providence and the "force of life". And it does so by bringing into play the rhetoric of 'sympathy' by Christopher S. Schmitt and Candance Clark, David Hume and Adam Smith's notion of "Enlightenment Sympathy" as ambidextrous which can be used as a comforting factor for exerting superiority. It is also presumed that Equiano's narrative present slavery as a moral evil and its practice of inflicting gruesome punishments by Christians is the height of hypocrisy. The objectives are to show the disconnection between the professed beliefs of the owners which has been passed onto Equiano and the violent racist creed which their faith is used to mask. The context of Equiano's resistance to slavery and the veneer of religion that is utilized to buttress its perpetuation is a lie supported by the authorities of the faith.

Equiano makes use of Milton's "Paradise Lost" to explain why many slaves often chose to seek death rather than continue to live under such conditions. Suicide in Christianity is a major sin, unpardonable sin. Equiano contends that if this is the case, the slaves must either continue under the oppression of God-sanctioned slavery or endure eternal divine judgment from seeking death's release, "By changing your conduct, and treating your slaves as men, every cause of fear would be banished" (Equiano 142). It is only by slave owners recognizing themselves as the true perpetrators of injustice that any such change would be possible. Michael L. Frazer argues that "sympathy, on the one hand, lessens the burden of the victim through narration of the painful

Assistant Professor of Saraswati Multiple Campus (Humanities Faculty: English Department), Tribhuvan University, Nepal. 
story and on the other hand gives pain to the sympathizer(s) too" (12) at the same time. It is also controversial because sympathy involves power relationship between sympathizer and the object of sympathy. Sympathizer feels himself to be superior and makes the sympathizers the victim all the time:

But sympathy is not simply a form of sentiment that holds communities together. It is also a kind of sentiment that travels quickly from person to person-a concept that makes frequent appearance in a variety of discourses throughout the period. 'Dangerous' passions, such as enthusiasm, are described in these terms, but so are other-regarding sentiments, like sympathy. And this mechanically-imagined concepts makes it possible that even in its philosophical conceptualizations sympathy can convey double meaning; it does not merely refer to an altruistic, benevolent, community forming capacity. (Csengei 40)

Equiano presented the self of his autobiographical narrative as a pious Christian, one whose religious conversion meant a kind of freedom as significant as his manumission from slavery. The Christian ethics he embraces is the defining feature of his force of life. Within the religious tradition of Protestant Christianity, Equiano seeks to tell the story of his soul's spiritual journey, to testify to God's actions in his life. Equiano is earnest and his consistent piety sets the tone and establishes the purpose of the narrative:

The worst word I ever heard amongst them when they were quarreling, was one that they had got from the English, which was, 'you rascal'. I never saw any mode of worship among them, but in this they were not worse than their European brethren or neighbors: for I am sorry to say that there was not one white person in our dwelling, nor anywhere else that I saw in different places I was at on the shore, that was better or more pious than those unenlightened Indians. (164)

For Romantics, slavery was perversion because the discourse of manifest destiny put forward by eighteenth century Europe was the "cradle of Modern Racism" (qtd. in Kitson, 11). Contemporary readers who dismiss the religiosity of Equiano's narrative follow the argumentative course and aesthetic sensibilities established by earlier respected readers such as Mary Wollstonecraft, who, in a 1789 review, admired many of the qualities of Equiano's text, most particularly his gripping account of his enslavement and his journey toward freedom.

Equiano's writing on the Middle Passage is the section of the work which is a profoundly evocative and devastating account of one of the most terrible events in human history: the forcible removal of millions of Africans from their home, and their subsequent transportation across the Atlantic in slave ships, under the most abominable and hellish conditions imaginable:

Many a time we were near suffocation, from the want of fresh air, which we were often without for whole days together. This, and the stench of the necessary tubs, carried off many. During our passage I first saw flying fishes, which surprised me very much: they used frequently to fly across the ship, and many of them fell on the deck. (39)

Slaves were chained to the hold and had to perform their bodily functions while chained. Excrement and refuse were everywhere, and the air was heavy with noxious, harmful smells. There was no privacy, even for woman and girls. Slaves could not move about and barely escaped 
without their limbs atrophying. They rarely had enough to eat or drink, and would grow sick in droves. The cries of pain, terror and grief filled the air at all times.

Equiano reveals the depth of his spirituality, and the extent to which he attributes, and the extent to which he attributes the circumstances of life to be a deity. Equiano claimed that he was born in Africa and practiced the religion of the Eboe land in which he was raised. That religion was not too different in its tenents and practices than that of the Jews, but Equiano soon learned about Christianity. Even before he converted, Equiano grew sensible of a God that existed and was aware of him:

And here I cannot forbear suggesting what has long struck me very forcibly, namely, the strong analogy which even by the sketch, imperfect as it is, appears to prevail in the manners and customs of my countrymen and those of the Jews, before they reached the Land of Promise. (12)

He often prayed and tried to order his behavior along Christian teachings, even believing himself to have offended God when Pascal sold him to Captain Doran. Schmitt and Clark contend that each social actor is entitled to a limited account of sympathy credits, or a "sympathy margin," with each of the many other actors in his or her network. An actor can claim, replenish, or entirely use up the credits in a particular sympathy margin:

As in the case with other gift givers, sympathizers typically gain micropolitical power or enhance their place vis-à-vis sympathizers, temporarily or over the long run.

Intentionally or not, they underscore their own generosity and generate feelings of obligations in the recipients. (Schmitt 480)

The people exchange sympathy so ubiquitously and with such nicety attests to deep-rooted cultural norms and social practices born of sympathy's central role in human interaction. We can observe Romantic sympathy's effects as a social emotion, social capital, a gift, an insult, negotiation, leverage, collateral, a bond, a catalyst, and as divisive force across the global landscape. The fact that Equiano was owned largely by benevolent men assures him of God's presence. Equiano is even baptized in 1759, although his conversion later in his life was a more profoundly impactful event in his spiritual growth.

Equiano introduces the worst of the worst offenders towards Africans-the cruel overseers of the cruel West Indies. Equiano is a good orator. Although he retains West's vision of commerce and capitalism as potential effectors of peaceful intercultural exchange, he also exposes the violence inherent in white men's relationship with indigenous populations, which west obscures, suggesting that compassion and non coercive religious instructions should characterize European relations with the less civilized. But perhaps the final image with which Equiano leaves his readers is one in which Africans like Equiano have replaced the Natives; in his plea that Britain abolish slavery and bring manufacturing to the continents many potential consumers. Equiano makes a bid for Africans, as the people most worthy of the civilizing efforts of Europe, efforts he deems desperately in need of reform, but whose fundamental righteousness he endorses:

For Hume, a good orator was a man who could touch the hearts of his audience: 'the principles of every passion; he tells us, 'and of every sentiment, is in every man; and when touched properly, they rise to life, and warm the heart'. In 'of Eloquence' Hume is not promoting, as Howell suggests, a simple endorsement of the old and the denial of the 
new. Rather, he is calling for a reconfiguration of the old to bring rhetoric in line with the growing movement to bring emotions to the force. (Carey 29)

The strategy Equiano used is sentimental rhetoric or the rhetoric of sensibility, and its purpose was to debate that slavery is gross inhumanity. It is highly unethical and the binary of slaves and slavers, blacks and white, Britons and Africans is nothing but assertion of his idea that whites are more cruel whereas Blacks are more religious than so called white enlightened Christians. Equiano publishes the narrative for his friends and in the hope that it might further "the interests of humanity" (179). Equiano assures his readers that he does not seek fame and fears that his life will not warrant telling by standards of the day because "people generally think those memoirs only worthy to be read... which abound in great or striking events....excite either admiration or pity" (181). He directly addresses the audience to think about the horrors of slavery both as Christians and people with families and friends.

Equiano relies on the rhetoric's of sympathy from the Christian religiosity which gives him strength to survive his ordeal, telling himself that he will free if and when God wills it. From the moment of his capture, Equiano longs to be free. He earned it. By his narrative the readers know that slavery is a moral evil and its practice of inflicting gruesome punishments by Christian is the height of hypocrisy.

\section{Works Cited}

Cary, Brycchan. British Abolitionism and the Rhetoric of Sensibility. Palgrave Macmillan, 2005. Print.

Csengei, Ildiko. Sympathy, Sensibility and the Literature of Feeling in the Eighteenth Century. Palgrave Macmillan, 2012. Print.

Equiano, Olaudah. The Interesting Narrative of the Life of Olaudah Equiano. Dodo Press, 1999. Print.

Frazer, Michael L. The Enlightment of Sympathy: Justice and the Moral Sentiments in the Eighteenth Century and Today. Oxford University Press, 2012. Print.

Kitson, Peter. "Candid Reflections": The idea of Race in the Debate over the Slave Trade and Slavery in the Late Eighteenth Century". Palgrave Macmillan, 2012. Print.

Schmitt, Christopher S. and Candace Clark. "Sympathy”. California: Springer, 2006. Print. 